\title{
Diagnosis and treatment strategies of thrombophilic risk factors
}

\section{Trombofilik risk faktörleri, takip ve tedavi stratejileri}

\author{
Osman Yokuş ${ }^{1}$, Özlem Şahin Balçık², Murat Albayrak ${ }^{3}$
}

\section{ABSTRACT}

Thrombophilia is defined as the general name for a group of genetic and acquired situations, arising from defects of hemostasis mechanism and generating tendency to thrombosis. Examples of the acquired risk factors that increase the tendency to thrombosis are venous catheters, sepsis, surgery, hyperlipidemia, congestive heart disease, increased lipoprotein a, old age, antiphospholipid syndrome, nephrotic syndrome, hyperviscosity, chronic myeloproliferative neoplasms, paroxysmal nocturnal hemoglobinuria, heparin induced thrombocytopenia, vasculitis, immobility, obesity, major surgery, trauma, burns, malignancy, pregnancy and oral contraceptive usage. Genetic tendency to venous thromboembolism in early ages, even without any known cause, is named as thrombophilia. Factor V Leiden, prothrombin G20210A, methylenetetrahydrofolate reductase gene mutations, factor VIII elevation, protein $\mathrm{C}$, protein $\mathrm{S}$ and antithrombin deficiency parameters are suggested for evaluation, in patient groups suspected of inherited thrombophilia. Detection of inherited thrombophilic factors in selected patient groups is a guide in developing treatment strategies and in establishing prognosis. Due to the genetic heterogeneities, each society should determine their thrombophilic risk pool. Thus, with the determination of the risk factors, unnecessary assessments will be prevented and a costeffective approach can be developed. J Clin Exp Invest 2010; 1(2): 125-133

Key words: Thrombophilia, venous thromboembolism, Factor V Leiden gene mutation; Prothrombin G20210A gene mutation

\section{INTRODUCTION}

Today, one of the most common causes of diseases and deaths are arterial and venous thrombi. Venous thromboembolism (VTE) diseases are in the third line after atherosclerotic cardiac diseases and stroke

\section{ÖZET}

Trombofili, hemostaz mekanizmalarındaki bozukluktan kaynaklanan ve tromboza eğilim oluşturan bir grup kaIıtsal ve kazanılmış durumun genel adı olarak tanımlanmaktadır. Tromboza eğilimi artırdığı bilinen kazanılmış risk faktörleri olarak santral venöz kataterler, sepsis, cerrahi, hiperlipidemi, konjestif kalp hastalığı, artmış lipoprotein a, yaşlılık, antifosfolipid sendrom, nefrotik sendrom, hiperviskozite, kronik miyeloproliferatif neoplazmlar, paroksismal nokturnal hemoglobinüri, heparine bağlı trombositopeni, vaskülit, immobilite, obesite, büyük cerrahi girişim, travma, yanık, malignite, gebelik ve oral kontraseptif kullanımı sayılabilir. Genç yaşta bilinen bir neden olmaksızın venöz tromboemboliye genetik yatkınlık, kalıtsal trombofili olarak tanımlanmaktadır. Faktör $V$ Leiden, protrombin G20210A, metilentetrahidrofolat redüktaz gen mutasyonları, faktör VIII yüksekliği, protein C, protein $S$ and antitrombin eksikliği parametrelerinin kalıtsal trombofili düşünülen hasta gruplarında araştırılması önerilmektedir. Kalıtsal trombofilik etkenlerin seçilmiş hasta gruplarında saptanmaları tedavi stratejileri geliştirmede ve prognozda yol gösterici olmaktadır. Her toplum genetik heterojenite nedeni ile kendi trombofilik risk havuzunu belirlemelidir. Bu şekilde trombofilik risk faktörlerinin belirlenmesi gereksiz tetkik istenmesini engelleyecek ve maliyet-etkin bir yaklaşım geliştirilebilecektir. Klin Den $\mathrm{Ar}$ Derg 2010; 1(2): 125-133

Anahtar kelimeler: Trombofili, venöz tromboembolizm, Faktör V Leiden gen mutasyonu, Protrombin G20210A gen mutasyonu

among cardio-vascular diseases 1 . While the prevalence of venous thromboembolism in the adults is $1 / 100.000$ in younger ages and it increases to the rate of $1 / 100$ in the older people. Frequently, VTE is observed in lower extremities. Occasionally, thrombosis may occur in other vascular localizations (i.e.

${ }^{1}$ Okmeydanı Education and Research Hospital Hospital Department of Hematology, Istanbul, ${ }^{2}$ Fatih University Medical School Department of Hematology, Ankara,

${ }^{3}$ Diskapi Yildirim Beyazit Education and Research Hospital Department of Hematology, Ankara, Turkey Yazıșma Adresi /Correspondence: Dr.Ozlem Șahin Balçık

Dizgi Sok. 9/6, 06120 Basinevleri Ankara / Turkey E-mail: drozlembalcik@yahoo.com

Geliș Tarihi / Received:20.03.2010, Kabul Tarihi / Accepted: 19.06.2010

Copyright @ Klinik ve Deneysel Araștırmalar Dergisi 2010, Her hakkı saklıdır / All rights reserved 
upper extremity, mesentery, portal, retinal, cerebral, hepatic and renal veins and arteries). It has been reported that $30 \%$ of the VTE experienced patients died in the first 30 days $^{2}$.

Thrombophilia is defined as the general name for a group of genetic and acquired situations, arising from defection of hemostasis mechanism and generating tendency for thrombosis. Examples of the acquired risk factors that increase the tendency to thrombosis are venous catheters, sepsis, surgery, hyperlipidemia, congestive heart disease, increased lipoprotein-a, old age, antiphospholipid syndrome (APS), nephrotic syndrome, hyperviscosity, myeloproliferative diseases, paroxysmal nocturnal hemoglobinuria $(\mathrm{PNH})$, heparin induced thrombocytopenia, vasculitis, immobility, obesity, major surgery, trauma, burns, malignancy, pregnancy and oral contraceptive usage ${ }^{3,4}$. Genetic tendency to VTE in early ages, even without any known cause, is named as thrombophilia. Inherited thrombophilic defect should be considered in cases, like spontaneous and recurrent thrombosis in early ages, thromboembolic events in family anamnesis, development of massive thrombosis in atypical areas, recurrent abortus in pregnancy, skin necrosis following the anticoagulant treatment. "Thrombophilia diagnosis" is made for patients who had recurrent thrombosis attack without any confirmed inherited thrombophilic factors or without diagnosis of $\mathrm{APS}^{5,6}$.

In random patient groups with VTE, all of the thrombophilic factors of thrombosis generating a tendency to thrombosis were determined in one third of the cases and more than half of those were diagnosed with inherited thrombophilia. Risk for thrombosis is also increasing, with the presence of combination of these defects.

Further investigation is suggested for some patient groups who developed clinical thrombosis, in the view of following parameters; Factor V Leiden (FVL), prothrombin G20210A (PTG), methylenetetrahydrofolate reductase (MTHFR) gene mutations, elevated factor VIII (FVIII), Antiphospholipid antibodies (APA) [Anticardiolipin antibodies and Lupus anticoagulant] and deficiencies of protein $\mathrm{C}$ (PC), protein S (PS)and antithrombin (AT). In literature, most data is available for these parameters to be related with thrombosis. The most common causes of acquired and hereditary thrombophilia are summarized in Table 1.

Although, frequency of inherited thrombophilic factors vary in many societies or patient groups, frequency of prothrombotic causes in societies becomes more clear, with the help of conducted studies.

Table 1. The most common causes of acquired and hereditary thrombophilia

\begin{tabular}{ll}
\hline Acquired & Hereditary \\
\hline Age & FVL Mutation (Activated Protein C Resistance) \\
Immobilization & PTG Mutation \\
Surgery & MTHFR Gene Mutation \\
Malignancy & PC Deficiency \\
Pregnancy & PS Deficiency \\
Oral Contraceptive Drugs & AT Deficiency \\
Hormone Replacement Treatments & Elevation of Factor VIII, Factor IX, Factor XI and Prothrombine \\
Antiphospholipid Antibodies (Anticardiolipin & \\
antibodies and Lupus anticoagulant) & \\
Chronic Myeloproliferative Neoplasms & \\
\hline
\end{tabular}

FVL: Factor V Leiden G1691A mutation; PTG: Prothrombin G20210A mutation; MTHFR: 5,10-methylenetetrahydrofolate reductase mutation; PC: Protein C; PS: Protein S; AT: Antithrombin 


\section{Inherited thrombophilia and Thromboembolism}

a. FVL mutation (Activated protein $C$ resistance $(A P C-R)$ : APC- active form of endogenous anticoagulant protein $\mathrm{PC}$ destroys and deactivates the active forms of factor V and FVIII. In 1993, APC-R was detected in some individuals with clinic hypercoagulability and this is thought to be inherited phenomena with autosomal dominant feature. Afterwards, the molecular defect accounting for APC-R, is found by Leiden as a single point mutation of $\mathrm{FV}$ gene. As a result of this mutation, arginine and glutamine replacement occurs in protein fragmentation point and active FV becomes partially resistant for break up by APC. This genetic defect accounts for $90 \%$ of the inherited thrombophilia cases and APCresistance.

FVL frequency varies in different ethnical groups. Even though the carrier rate of Caucasians is between 3-5\%, it is rarer in Asian and African populations. Most common clinical symptom of FVL is deep vein thrombosis (DVT). Acquired APC-R may be observed in pregnancy, estrogen usage, older age and APS and FVIII elevation. In the case control studies, DVT risk is showed to be increased 5-10 folds in FVL heterozygote cases and $80 \%$ in homozygote cases. Consequently, $50 \%$ of thromboembolic cases with undetermined predisposing factors can be explained with FVL (APC-R) mutations. APC-R is one of the most important causes of hypercoagulability?

a. PTG mutation: Prothrombin is the precursor molecule of thrombin, activating FV and FVIII, and converts fibrinogen to fibrin. As a result of the mutation of the allele in 20210A nucleotide position of the prothrombin gene, prothrombin level increases and tendency to venous thrombosis occurs. PTG gene allele is confirmed as one of the most common genetic factors that related with venous thrombosis.

Its prevalence is approximately $5-6 \%$ in unselected DVT patients, $0.7-3 \%$ in control group, $18 \%$ in patients with family history of thrombosis. Heterozygote PTG careers have 2-5 folds increased risk of thrombosis comparing with the unaffected control group. DVT recurrence risk increases 2-4 folds. VTE risk is increased in patients with PC, PS, AT deficiency and FVL mutation more than the patients with PTG mutation ${ }^{8}$. b. MTHFR gene mutation and Hyperhomocysteinemia: Thermolabile homozygote mutated forms of MTHFR enzyme is a genetic abnormality which is more common and which causes moderate hyperhomocysteinemia. It is suggested that in vitro homocysteine antagonizes the synthesis and function of nitric oxide and causes vascular endothelial damage and develops a thrombogenic effect through many different ways. There are also evidences proving that, moderate hyperhomocysteinemia may cause coroner artery disease and occlusive arterial disease and particularly with the presence of other thrombophilic situations, it increases the risk of VTE to 2.5 folds. The increased risk of VTE with the elevation of homocysteine is more frequent in women than men and the risk becomes higher with the elder age. Hyperhomocysteinemia is the thrombophilic factor which is easiest to treat. The association between thermolabile MTHFR gene variant and thrombosis is not independent and the risk of thrombosis increases proportionally with the elevation of homocysteine levels which is determined by complex relationship between genetic and environmental factors. It increases the risk of thrombosis when combined with FVL mutations. Patients with these two defects concurrently, the risk of VTE is increased 10 folds comparing with normal control group; however, the risk is moderate in people with one single defect. The two most common heritable polymorphisms are C677T and 1298 position polymorphisms of MTHFR gene. In Caucasians, prevalence of C677T polymorphism is 6-12\% ${ }^{1}$.

c. Protein C, Protein $S$ and Antithrombin Deficiencies: Deficiency of endogenous anticoagulant proteins PC, PS and AT is the first determined genetic cause of thrombophilia. In unselected patients among those admitted with DVT, the frequency of these 3 defects is approximately $7 \%$. Usually these defects are inherited in an autosomal dominant condition and homozygote cases generally die intrauterine or shortly after birth. Clinic expression of heterozygote cases varies with clinic phenotype expressions and presence of other clinic and genetic abnormalities which cause tendency for thrombo$\operatorname{sis}^{1,8}$.

Protein C: Synthesized in the liver depending on vitamin $\mathrm{K}$ (K-vit). PC transforms to APC with the combination of thrombomoduline and thrombin in the endothelial surface. APC inactivates FVa 
and FVIIIa with contribution of PS. There are two types of defects; Type I (quantitative) and Type II (qualitative). Prevalence of PC defect is determined in general population in a rate of $0.2-0.3 \%$ and in patients experienced one thrombosis attack in a rate $3 \%$. This rate decreases in liver disease, $\mathrm{K}$-vit deficiency, oral anticoagulant usage and disseminating intravascular coagulation (DIC). In the state of acute thrombosis, it may decrease due to the consumption; therefore the results are not reliable. Annual thromboembolism incidence was calculated in a rate of $2.5 \%$ in patients with PC defect, who have not experienced any thrombi, but there is a family history. VTE development is also seen in $50 \%$ of patients around the age of 45 , with a family history of heterozygote PC deficiency.

Protein S: It is mostly synthesized in the liver, depending on vitamin-K. It is the co-factor of PC. Active part is the free form. In the FVIII elevation and FVL presence, false decrease may be seen. PS may be decreased in following situations; inflammation, pregnancy, presence of APA and situations that cause decreased PS. Prevalence of PS deficiency is approximately $1-2 \%$. Family individuals of patients with PS deficiency have increased risk for thromboembolism. Thrombosis is in idiopathic, juvenile and recurrent characteristics.

Antithrombin is an endogenous anti-coagulant that inhibits the biological activities of thrombin and other coagulation cascade, binding their active coagulation factor. Two types of deficiency are described; Type I (quantitative) and Type II (qualitative). AT affects with inhibition of factor IX, X, XI, XII. Its effect is 1000 fold more than heparin's effect and if combined with heparin sulphate, this effect increases. Frequency of deficiency is $0.02 \%$ in normal population and this rate is approximately $1 \%$ in cases with thrombosis. Homozygote deficiency is rare and not compatible with life. Acquired AT deficiency may be found in cases such as liver disease, nephritic syndrome, DIC, L-asparaginase treatment, pregnancy and heparin usage, although it may decrease in acute consumption.

d. Elevation of coagulation factor and thrombophilia: Factor VIII (FVIII), factor IX (FIX), factor XI (FXI) and prothrombine is reported as the independent risk factors for $\mathrm{VTE}^{9}$. In the case of idiopathic recurrent VTE, measurements of FVIII level are suggested, and if high levels are deter- mined, long-term anticoagulant administration may be considered ${ }^{10,11}$.

\section{Reasons of acquired thrombophilia}

One of the most common acquired thrombophilia factors is malignity. Cancer patients are in a hypercoagulable state, even though they do not have thrombosis. Pathogenesis of thrombosis in cancer is multifactorial. Two main mechanisms of development of prothrombic thrombosis are; interacting capacities of tumor cells with homeostatic mechanisms and anti-tumor treatment.

a. Antiphospholipid antibodies (APA): It is one of the common acquired thrombophilic factors. APS is thrombophilic, immunologic syndrome, deriving from heterogeneous auto-antibodies which developed against biological membranes that mainly originate from phospho-lipid components. Clinical symptoms of this syndrome are arterial and venous thrombosis, recurrent abortus and thrombocytopenia, and serologic findings are IgG or IgM anticardiolipine antibodies (ACA) or presence of Lupus anticoagulant (LA). At least one serologic finding should be present with a clinical finding in order to make the diagnosis ${ }^{12}$.

Frequency of ACA is between 1-9\% in general population. Myocardial infarction and other arterial vascular areas are proven to be independent factors for thrombosis and recurrence of thrombosis. APS may be caused by primer or secondary (systemic lupus erythematosus, malignancy, infections, and drugs) factors. While its frequency in general population is $1-5 \%$, this rate is $12-30 \%$ for ACA and it reaches to $15-44 \%$ for $\mathrm{LA}$.

In the presence of recurrence of thrombotic events, life-treating thrombotic events or high titrate AFA, long-term or lifelong prophylaxis may be needed $^{13,14}$.

b. Oral Contraceptive, Hormone Replacement Treatments and Thrombophilia: Women, taking hormone replacement treatment (HRT) have 2-5 times increased risk of VTE comparing with the others. Patients taking higher dose or single estrogen containing drugs have increased risk in regards to the thromboembolic events compared to lower dose estrogen or combined therapy (estrogen plus progesterone) prescribed patients. Thrombophilia increases the risk of VTE particularly with the presence of FVL and HRT. Overweighing and old age 
are additional factors that increase the risk. Before prescribing oral contraceptive drugs, thrombophilia screening tests should be performed to the individuals a history of VTE ${ }^{15}$.

c. Pregnancy and the risk of thrombosis: The risk of developing early, recurrent and late abortions, pre-eclampsia, abruptio placentae and intrauterine growth retardation are increased in thrombophilic defective patients. Most increased thrombosis risk in pregnancy was found to be accompanying with FVL mutations. Particularly, pregnant patients with homozygote form of this mutation, have 34-foldsincreased risk of VTE comparing with the normal pregnancies ${ }^{15}$. Thrombophilia screening is suggested for individuals who have a history of VTE in pregnancy, personal and family history ${ }^{16}$.

d. Surgery and Thrombophilia: Post-operative VTE, pulmonary embolism (PE) and FVL were significantly related to PTG mutations and FVIII elevation. AT deficiency, MTHFR and hyperhomocysteinemia are not found to be related with VTE risk. Screening of the sub-groups with the history of VTE among who have the possibility for thrombophilia is much more cost-effective than screening of the general population ${ }^{17}$.

3. To whom and when the thrombophilia screening test should be required? Thrombophilia screening aims to determine the patient who may benefit from long-term anticoagulation treatment and needs for prophylactics in risky status. In a study, a cost effectiveness analyze was assessed in two groups of patients with a family history of inherited thrombophilia who were evaluated before surgery, pregnancy, birth and OKS vs. those who were not evaluated. It was emphasized that cost would be decreased with the thrombophilia screening tests before the risky situation, in such selective patient sub-groups with personal and family history of thromboembolism ${ }^{18}$.

The individuals, who had a previous spontaneous VTE attacks or recurrent thrombotic attacks before age 50 and who had a family history of thrombosis at close relatives, are suggested to be evaluated for PC, PS and AT deficiency, APC-R, PTG mutation, APA and plasma homocysteine levels ${ }^{19,20}$.

In patients with VTE, routine thrombophilia test should be performed when an abnormality is observed, if duration and type of anticoagulant treatment will be changed. In our knowledge, there is no difference in the way of anticoagulation between the patients with or without thrombophilic factors, other than APS $^{21}$. Laboratory analyses and the frequency of the disease were investigated in patients with spontaneous development of thrombosis and in the control group in sporadic areas, and inherited thrombophilia was found to be more frequent in thrombotic cases. Thrombophilia screening is suggested for patients with spontaneous thrombosis (except central retinal vein thrombosis) ${ }^{22}$.

Natural anticoagulant levels decrease due to consumption in acute thrombosis. Heparin - dependent AT, warfarine - bounded PC and PS decrease. However, genetic tests are not affected by the treatments. Treatment is not effected by any diagnosed defect during acute thrombosis. Phenotypical test should be performed after 3 months of acute thrombotic event and minimum two weeks after the discontinuation date for oral anticoagulant treatment. If anticoagulant treatment cannot be discontinued, warfarine should be discontinued and switched to heparin. After 10 days of switch, PC ad PS can be performed.

\section{Thrombophilia and tThrombosis presentation}

a. Ischemic Stroke (IS): Generally, IS is a situation that occurs depending on arterial disease (carotid stenosis, etc) or cardiac disease (atrial fibrillation, etc). Studies on the role of inherited thrombophilia shows different results about presence of thrombophilic factors, different vessel involvement areas and ethnic group differences in the etiology of cerebral artery and venous thrombosis (CAT, CVT). It was reported that IS is responsible for $1-4 \%$ of hypercoagulable events but inherited thrombophilia have the greatest portion of inheritance in younger sub-group of IS patients. In some studies, while the role of inherited thrombophilia in IS etiology cannot be determined, PC deficiency, FVL and PTG gene mutation are found more frequent in SVT ${ }^{23,24}$.

Presence of MTHFR gene mutation and elevation of homocysteine levels are found to be related with increased SVT risk, particularly accomplishment with low folate level and in populations with lower socio-economical status. Thrombophilic tests are recommended for young IS patients that etiology cannot be explained, particularly if they have personal and family history of thrombosis. 
b. Retinal vessel thrombosis: Central retinal vein and retinal artery thrombosis (retinal vascular thrombosis: RVT), are the most common vascular diseases of the eye and general cause of serious vision loss. Usual causes of retinal embolism are stasis, increase in viscosity and thrombus. Relationship between thrombophilic risk factors and RVT is needed to be clarified. Some of risk factors such as; arterial hypertension (HT), diabetes mellitus (DM) and atherosclerosis are important in the etiology. Hyperhomocysteinemia, MTHFR gene polymorphism and APS result in central RVT, and as a cause, hyperfibrinolysis is a major factor. In some studies, however, thrombophilia frequency is demonstrated to be similar with control group, which means it is not a risk factor. Thrombophilic factors cannot be defined to be a prominent factor for $\mathrm{RVT}^{25,26}$.

c. Pulmonary embolism (PE): PE is a multi-factorial etiologic clinic manifestation which develops secondary to DVT, usually, at the lower extremities. $6 \%$ of PE results in death. Prevalence varies with age and ethnic group. Inherited thrombophilia is determined as a cause of non-predisposal factor of $35 \%$ cases.

Acquired risk factors for PE development are inherited factors, FVL, PTG, PC, PS, AT deficiencies as well as acquired risk factors such as, estrogen replacement, cancer, cardiovascular disease, surgery, trauma, immobility, central venous catheter usage. Risk increases with the combination of genetic and acquired factors ${ }^{27}$.

d. Upper extremity vessel thrombosis (UEVT): It is a rare thrombotic event. Generally, thrombosis develops due to the acquired predisposing factors, i.e; catheter, malignity, exercises. The role of thrombophilia in pathogenesis is not well $\mathrm{known}^{28}$. In a study, evaluating the acquired and inherited thrombophilia factors that have a role in spontaneous UEVT etiology, less than $61.3 \%$ of cases were diagnosed with a coagulation abnormality ${ }^{29}$. APA is determined as the most common factor.

e. Abdominal vessel thrombosis: Abdominal vessel thrombosis inventory is frequently related with congenital and acquired thrombophilia in adults, and related clinic presentations may vary. Portal vein thrombosis (PVT), Budd-Chiari Syndrome, mesenteric vein thrombosis can be accomplished with acute abdominal syndrome, chronic hepatomegaly and even with asymptomatic pan- cytopenia. Also these manifestations may cause to some complications i.e.; esophageal varices, portal gastropathy, ascite, serious hypersplenism, liver failure that requires transplantation. In complications of intraabdominal vessel thrombosis, treatment strategies are not different from hypertension treatment however prognosis is better ${ }^{30}$.

\section{f. Placental vascular thrombosis (Habitual} abortus): Some changes in coagulation system occur in order to prevent the bleeding complications in normal pregnancies. The risk of thrombosis is increased in pregnant. Thrombophilia screening tests should be performed in pregnancy or puerperiumrelated VTE, in 2 or more abortus and in fetal intrauterine death cases, occurring in 1st or 2nd trimester. Routine thrombophilia screening is suggested in pregnancy $^{31}$. VTE in pregnancy is one of the major factors that increase the maternal mortality and morbidity. Most of these deaths can be prevented with optimal prophylaxis and treatment strategies. VTE risk is elevated 3 to 15 fold in pregnancy. Recurrence risk is increased 3.5 folds in patients who previously experienced a VTE. Acquired thrombophilic risk factor was detected in $2 / 3$ of pregnancies and inherited thrombophilic risk factor was detected $30-50 \%$ of pregnancies among who experienced VTE.

g. Arterial thrombosis and thrombophilia: Although in small studies with children and young women, it was suggested that thrombophilia has a role in arterial thrombosis, it could not confirmed with large-scaled studies. Presence of FVL and PTG mutations may increase the risk. Through the investigation of inherited thrombophilia factors in young patients who experienced thrombosis in arterial fields, without presence of conventional risk factors (i.e.; smoking, HT, DM), thrombophilia frequency has shown a mild increase ${ }^{32}$.

\section{Treatment and prophylaxis}

Annual incidence of recurrence in VTE is $5-10 \%$ that is assessed as a chronic disorder. Patients with VTE should take an anticoagulant treatment for at least 3 months. Treatment duration should be determined with the assessments of response to treatment and possible complications. Patients with high risk of recurrence should be determined and considered for long-term treatment. Patients with AT deficiency, LA positivity, FVL (homozygote), pres- 
ence of combined inherited defect or more than one thrombosis episodes are predicted to have high risk of recurrence.

Primarily, low-molecular-weight heparin (LMWH) or heparin is initiated with warfarin and treatment is continued for 5 days. When the international normalized ratio (INR), range is between 2 and 3 for 2 subsequent days, warfarin is discontinued (if not pregnant).

Generally after the first attack, 6 months treatment is prescribed, however, if the distal vein thrombosis is present and triggering event is temporary, 3 months of warfarin treatment is prescribed. If thrombosis reoccurs at the end of treatment, anticoagulation is initiated as the same way. Treatment is maintained with an INR range of 2-3. If recurrence occurs, dose escalation is made to INR 3-4 range. For the treatment of patients with congenital AT deficiency, AT concentrates can be given with intravenous heparin treatment ${ }^{33,34}$.

a. Treatment and prophylaxis of pregnant with thrombophilia: Pregnant women with PS deficiency, heterozygote FVL and PTG mutations have low risk and thromboprophylaxis is not recommended. However, thromboprophylaxis is suggested for inherited thrombophilic pregnant who develops complications, such as recurrent abortions, intrauterine fetal death and severe preeclampsia, in case of a 4-hours flight trip or additional thrombotic risk factor. Pregnant with PC and AT deficiency, homozygote mutations of FVL and PTG and other combined thrombophilic defects, has moderate thrombosis risk. Thrombophylaxis is suggested for these patients either in gestation or in puerperant periods. Cumarin derivations are not safe due to embriopathy and fetal bleeding risk.

LMWH's are safer comparing with unfractioned heparin. If VTE is suspected in pregnant, anticoagulant treatment should be continued if there is no contraindication, until VTE absence is showed. Heparin is used in pregnant with prosthetic heart valves $^{35}$.

b. Prophylaxis in surgery: Prophylaxis is not necessary for patients under the age of forty, if no additional risk factor is present and anesthesia duration is below 30 minutes.

Risk level is moderate in patients over the age of forty and anesthesia duration over 30 minutes, starting from the 12 hours prior to the surgery; low dose standard heparin or one dose LMWH is suggested. Patients undergoing to major surgery and aged over 40 with the additional risk factors, will be are accepted in the high risk group and prophylaxis is suggested during 7-10 days.

c. Prophylaxis in malignancies: Results were published indicating that DMWH treatment is more effective than warfarin in case of malignancy complications with thrombosis ${ }^{36}$.

\section{CONCLUSION}

Thromboembolism is a clinic entity that is common in adults and its etiology is generally multifactorial. There are increasing numbers of publications, showing that the roles of inherited defects are important as much as acquired factors in the etiology of thrombosis in adults ${ }^{37}$. It is well known that frequency of defects, which are assessed in thrombophilia screening, varies in different populations and ethnic groups even in different geographical regions. With proved thrombophilia factors; PC, PS, AT deficiency, FVL mutation, APC-R, PTG and MTHFR mutation, FVIII elevation, tests for ACA and LA, that may affect the dose and duration of treatment, should be added to inherited thrombophilia screening list.

Since $1 / 3$ of thrombophilia cases are determined with combined thrombophilic defects, it is suggested that after detection of one positive factor, tests should be continued with screening of at least 3 or 5 common defects. Furthermore, combined defects have critical importance in order to decide for duration and concentration of treatment. Treatment strategy is unclear, however long-term anticoagulant treatment is recommended in the presence of APS. Thrombophilic treatment recommendations should be given in consideration of thrombosis which may have acquired or inherited etiological origin in vein or artery, with temporary or permanent characteristics. The risk for recurrence after 5 years of thrombosis attack is $24 \%$ and following 8 years, it is approximately $30 \%$. Long-term anticoagulation may be considered in such cases of two or more spontaneous thrombosis attack or spontaneous thrombosis at one of the life-threading regions (cerebral, mesentery, almost fatal PE), spontaneous thrombosis+APS combination, AT deficiency or defect of more than one genetic allele (homozygote 
FVL, more than one heterozygote combine defects) 38 .

Training of patients for symptoms and clinical symptoms of thrombosis and disease ID cards for patients is suggested.

Treatment strategies are not completely identified for thrombosis of inherited thrombophilic cases. Due to the risk of serious bleeding complication, fibrinolytic treatment is not widely used. Different treatment strategies should be decided with the consideration of patients' clinic situation and frequency of thrombosis.

In brief; determination of inherited thrombophilic factors in selected patient groups will be guide for development of treatment strategies and prognosis. Due to the genetic heterogeneities, each society should determine their thrombophilic risk pool. Thus, with the determination of risk factors, unnecessary assessments will be avoided and a costeffective approach will be developed.

\section{REFERENCES}

1. Deitcher SR, Rodgers GM. Thrombosis and Antithrombotic Therapy. In: Greer JP, Foerster J, Lukens JN, et al, eds. Wintrobe's Clinical Hematology, 11 Th ed. Philadelphia: Lippincott Williams and Wilkins; 2004. P. 1713-28.

2. Yehezkely-Schildkraut V, Kutai M, Hugeirat Y, et al. Thrombophilia: a risk factor for cerebral palsy? Isr Med Assoc J 2005;7:808-11.

3. Lawson SE, Butler D, Enayat MS, Williams MD. Congenital thrombophilia and thrombosis: a study in a single centre: Arch Dis Child. 1999; 81:176-8.

4. Bauer K. Hypercoagulable states. Hematology 2005;10 (Suppl 1):39-42.

5. Sucak G, Haznedar R. Trombofili. Türkiye Klinikleri Cerrahi Dergisi 2000;5:59-64.

6. Schved JF. Definition of thrombophilia. Ann Med Interne (Paris). 2003;154:279-82.

7. Oymak S, Ünal A, Çetin M, Gülmez İ, Demir R, Özesmi M. Aktive Protein $\mathrm{C}$ rezistansına bağlı ailevi trombofili. Erciyes Tip Dergisi 1998;20:70-4.

8. Pathare A, Alkindi S, Albalushi T, Bayoumi R, Dennison D, Muralitharan S. Heterozygous methylene tetrahydrofolate reductase mutation with mild hyperhomocysteinemia associated with deep vein thrombosis. Clin Lab Haematol 2004;26:143-6.

9. Bertina RM. Elevated clotting factor levels and venous thrombosis. Pathophysiol Haemost Thromb 2003;33:395-400.

10. Bobrow RS. Excess factor VIII: a common cause of hypercoagulability. J Am Board Fam Pract 2005;8:147-9.

11. Siegemund A, Petros S, Siegemund T, Scholz U, Seyfarth HJ, Engelmann L. The endogenous thrombin potential and high levels of coagulation factor VIII, factor IX and factor XI. Blood Coagul Fibrinolysis 2004;15:241-4.

12. Arıcan O, Okan, Aycan S, Kozan O. Primer antifosfolipid sendromlu genç kadın hastada miyokard infarktüsü. MNKardiyoloji Dergisi 2004;11:221-3.

13. Poli D, Gensini GF. Antiphospholipid syndrome and venous thromboembolism: the role of congenital thrombophilia. Ann Ital Med Int 2005;20:218-23.

14. de Groot PG, Lutters B, Derksen RH, Lisman T, Meijers JC, Rosendaal FR. Lupus anticoagulants and the risk of a first episode of deep venous thrombosis. J Thromb Haemost 2005;3:1993-7.

15. Tripodi A. Issues concerning the laboratory investigation of inherited thrombophilia. Mol Diagn 2005;9:181-6.

16. Camargo EC, Massaro AR, Bacheschi LA, et al. Ethnic differences in cerebral venous thrombosis. Cerebrovasc Dis 2005;19:147-51.

17. Wu O, Robertson L, Twaddle S, et al. Screening for thrombophilia in high-risk situations: systematic review and costeffectiveness analysis. The Thrombosis: Risk and Economic Assessment of Thrombophilia Screening (TREATS) study. Health Technol Assess 2006;10:1-110.

18. Blickstein D. Screening for thrombophilia. Obstet Gynecol Clin North Am 2006;33:389-95.

19. Pottier P, Cormier G, Truchaud F, Planchon B. Efficiency of systematic thrombophilia screening in idiopathic venous throm-bosis: a prospective study in internal medicine. Clin Appl Thromb Hemost 2005;11:243-51.

20. Beyan C. Trombofilili hastada tanısal yaklaşım. Turkiye Klinikleri J Int Med Sci 2005;1:71-81.

21. Bombeli T, Basic A, Fehr J. Prevalence of hereditary thrombophilia in patients with thrombosis in different venous systems. Am J Hematol 2002;70:126-32.

22. Fegan CD. Central retinal vein occlusion and thrombophilia. Eye (Lond). 2002;16:98-106.

23. Hankey GJ, Eikelboom JW, van Bockxmeer FM, Lofthouse E, Staples N, Baker RI. Inherited thrombophilia in ischemic stroke and its pathogenic subtypes. Stroke 2001;32:1793-9.

24. Cantu C, Alonso E, Jara A, et al. Hyperhomocysteinemia, low folate and vitamin B12 concentrations, and methylene tetrahy-drofolate reductase mutation in cerebral venous thrombosis. Stroke 2004;35:1790-4

25. Marcucci R, Bertini L, Giusti B, et al. Thrombophilic risk factors in patients with central retinal vein occlusion. Thromb Haemost 2001;86:772-6.

26. Weger M, Renner W, Steinbrugger I, et al. Role of thrombophilic gene polymorphisms in branch retinal vein occlusion. Oph-thalmology 2005;112:1910-5.

27. Gathof BS, Picker SM, Rojo J. Epidemiology, etiology and diagnosis of venous thrombosis. Eur J Med Res 2004;9:95103.

28. Ellis MH, Manor Y, Witz M. Risk factors and management of patients with upper limb deep vein thrombosis. Chest 2000;117:43-6.

29. Hendler MF, Meschengieser SS, Blanco AN, Alberto MF, et al. Primary upper-extremity deep vein thrombosis: 
high prevalence of thrombophilic defects. Am J Hematol 2004;76:330-7.

30. Bayraktar Y, Harmanci O. Etiology and consequences of thrombosis in abdominal vessels. World J Gastroenterol 2006; 12:1165-74.

31. Robertson L, Wu O, Langhorne P, et al. Thrombosis: Risk and Economic Assessment of Thrombophilia Screening (TREATS) Study. Thrombophilia in pregnancy: a systematic review. Br J Haematol 2006;132:171-96.

32. Böhm G, Al-Khaffaf H. Thrombophilia and arterial disease. An up-to-date review of the literature for the vascular surgeon. Int Angiol 2003;22:116-24.

33. Kyrle PA. The optimal duration of secondary thromboprophylaxis in patients with venous thromboembolism.
The importance of thrombophilia screening. Wien Med Wochenschr 2005;155):17-21.

34. Tsanadis G, Vartholomatos G, Korkontzelos I, Avgoustatos F, et al. Polycystic ovarian syndrome and thrombophilia. Hum Reprod 2002;17:314-9.

35. Kafkas S, Kadıköylü G. Gebelik ve kalıtsal trombofili. ADÜ Tıp Fakültesi Dergisi 2005;6:43-50.

36. Bauer KA. Role of thrombophilia in deciding on the duration of anticoagulation. Semin Thromb Hemost 2004;30:633-7.

37. Lawson SE, Butler D, Enayat MS, Williams MD. Congenital thrombophilia and thrombosis: a study in a single centre. Arch Dis Child 1999;81:176-8.

38. Greer IA. Venous thromboembolism and anticoagulant therapy in pregnancy. Gend Med 2005;2 Suppl A:S10-7. 